\title{
Carl Schmitt, Jurista das Forças armadas \\ O Estado militar prussiano contra \\ O Estado de direito burguês
}

\section{Carl Schmitt, army forces Jurist: the Prussian military state in opposition to the bourgeois 'De Iure' state}

\author{
David Cumin ${ }^{1 *}$
}

\section{Resumé}

Staatsgefüge und Zusammenbruch des Zweiten Reiches. Der Sieg des Bürgers über den Soldaten est un livre méconnu de Carl Schmitt, alors qu'il est le plus révélateur de ses passions politiques. Le juriste analyse le constitutionnalisme allemand du XIXème siècle avec l'intention de découvrir les causes de la défaite de 1918. Les principes de la démocratie occidentale montaient à l'assaut de la constitution bismarckienne, qui était elle-même un compromis avec cette démocratie occidentale. A travers l'histoire et le droit constitutionnels wilhelminiens, il veut montrer comment le travail de sape du libéralisme contre l'Etat militaire a provoqué l'effondrement du IIème Reich.

Mots-clés : Schmitt, Constituionnalisme allemand, Democratie, Reich.

\section{Resumo}

Staatsgefüge und Zusammenbruch des Zweiten Reiches. Der Sieg des Bürgers über den Soldaten é um livro desconhecido de Carl Schmitt, enquanto ele é o mais revelador de suas paixões políticas. O jurista analisa o constitucionalismo alemão do Século 19 com a intenção de descobrir as causas do defeito de 1918. Os princípios da democracia ocidental tomam de assalto a constituição bismarckiana que era ela mesma um compromisso com esta democracia ocidental. Através da história e do direito constitucional wilhelmianos, ele quer mostrar como o trabalho destruidor do liberalismo contra o Estado militar provocou o afundamento do $2^{\circ}$ Reich.

Palavras-chave: Schmitt, Constitucionalismo alemão, Democracia, Reich.

\footnotetext{
*David Cumin - Professor Doutor e Mestre de conferências (HDR) na Universidade Jean Moulin Lyon III (CLESID). Tradução: Agemir Bavaresco (PUCRS), Danilo Vaz-Curado Ribeiro de Menezes Costa (UNICAP/PE) e Wellington A. Silva (PUCRS).
} 
A obra de Carl Schmitt (1888-1985) girava em torno de instituições ao mesmo tempo hierocráticas e androcráticas: a Igreja e as Forças armadas. Conhece-se o teólogo. Conhece-se um pouco menos o Kronjurist do Reichswehr. Staatsgefüge und Zusammenbruch des Zweiten Reiches. Der Sieg des Bürgers über den Soldaten (1934) ${ }^{21}$ é um livro desconhecido de Schmitt; ele é entretanto o mais revelador de seu pensamento político, ou mais precisamente de suas paixões políticas. Torna-se assim, necessário apresentá-lo. Nele se reencontra o teórico do direito da crise e da relação amigo-inimigo.

A doutrina de Carl Schmitt se inscreve na tradição do direito público que foi determinada pela situação específica da monarquia constitucional alemã da segunda metade do século 20 e pela filosofia hegeliana do Estado, com sua distinção fundamental entre Estado e Sociedade. Esta distinção nosso jurista radicaliza num sistema de antíteses que alcança seu ponto extremo em 1934, com a oposição entre o Estado militar prussiano e o Estado liberal burguês. O conflito constitucional prussiano de 1862-1866 é, deste ponto de vista, o momento decisivo da história político-jurídica alemã de 1848 à 1918. Essas duas datas marcam duas reviravoltas. Schmitt as coloca sobre uma mesma linha de desenvolvimento histórico, aquela que viria explodir os compromissos da monarquia constitucional até seu desaparecimento.

Em 1934, 1937 e 1939², Carl Schmitt analisa o constitucionalismo alemão do século 20 com a intenção de descobrir as causas da catástrofe de 1918, de que ele havia sido testemunha em Munique quando estava sob os estandartes. Desde 1930, ele anuncia a ideia central dos textos publicados sob o Terceiro Reich: o conflito, latente desde 1848 mas sempre adiado, entre o governo monárquico e o parlamento, torna-se mais e mais agudo

\footnotetext{
${ }^{2} \quad{ }^{1} \mathrm{Cf}$. As referências completas dos textos de Carl Schmitt na bibliografia.

32 Staatsgefüge und Zusammenbruch des Zweiten Reiches..., « Nationalsozialismus und Rechtsstaat », " Totaler Feind, totaler Krieg, totaler Staat », « Neutralität und Neutralisierungen...».

98 - Universidade Católica de Pernambuco
} 
em razão e à medida que se agravava a situação diplomática e militar ao curso da guerra mundial. Os princípios da democracia ocidental tomaram de assalto a constituição bismarckiana, que era ela mesma um compromisso com a democracia ocidental. Era, portanto, impossível, do lado alemão, estabelecer uma trincheira alternativa entre ideais constitucionais opostos. ${ }^{43}$

A sua maneira, Schmitt compreende a história político-jurídica da Alemanha de 1848 a 1918, marcada, de acordo com ele, por um longo conflito entre os corpos dos funcionários e oficiais prussianos e a burguesia liberal, conflito intensificado pela ascensão do proletariado socialista. Através da história e do direito constitucional Wilhelmianos, ele quer mostrar como o insidioso trabalho de erosão do liberalismo contra o estado militar provocou o colapso do Segundo Reich. Ao mesmo tempo, ele justifica a liquidação do Estado de Direito regime estrangeiro e hostil a nossa tradição ${ }^{54}$, e o advento do nacional-socialismo. Enfim, à época da defensiva, sendo completado pela armada prussiana, o qual é objeto de um verdadeiro elogium, aquele pode e deve tornar a ser o núcleo do Reich.

\section{O Estado militar prussiano no Século XIX}

Segundo Carl Schmitt, o Estado militar prussiano foi a verdadeira forma da existência política do povo alemão. É na Monarquia dos Hohenzollern e, após, no Estado-Maior que o Reich, unificado pela Prússia, encontra sua direção e sua organização políticas. Mas, este Estado, ao longo do século XIX, teve que se colocar sob a defensiva em face das reivindicações liberais, depois socialistas.

A revolução de 1848, o constrangeu a aceitar uma constituição e um governo constitucional. Ao aceitar o constitucionalis-

\footnotetext{
${ }^{4} \quad{ }^{3}$ Hugo Preuss..., pp.16-17. Cf. Mesmo que eufemizadas as pp.477-483 de Théorie de la Constitution [Teoria da Constituição], assim como Terra e Mar, p.87.

$5 \quad 4$ «Die Verfassung der Freiheit », p.1134.
} 
mo, o Estado prussiano pôs em causa seu princípio monárquico. Aparecendo uma estrutura dualista que gerou um conflito constitucional permanente entre o Governo e o Parlamento, entre o Estado e a Sociedade, entre as forças armadas e os partidos. Esse conflito coloca-se principalmente sob o orçamento militar, isto é, no núcleo do Estado e termina por deslocar a unidade nacional.

\section{a) O Antagonismo do Soldado e do Burguês}

O compromisso burguês-legitimista do século XIX, segundo expressão de Hitler, repetida por Schmitt, era profundamente estranho à natureza do Estado prussiano. O conflito constitucional mostra, claramente, não a distinção que poderia ter havido entre monarquia constitucional e monarquia parlamentar - esta distinção, nosso jurista a julga por demais sem importância, pois a lógica mesma do constitucionalismo conduz ao parlamentarismo - mas a oposição fundamental entre o soldado e o burguês. Essa oposição, afirma-o Schmitt, é irredutível a toda conciliação, pois ela não é uma simples divisão de poderes, ela nutre-se de um conflito identitário.

A Alemanha seria dominada por valores marciais e heróicos ou pelos valores mercantis e hedonistas? Por detrás do dualismo entre a monarquia militar e o constitucionalismo liberal emerge algo mais profundo que o conflito político em torno do governo: a oposição de duas ordens valorativas e de dois tipos humanos. A situação do proletariado acentua ainda mais esta problemática. Enquanto que sua organização nos sindicatos e no partido socialista, de Lassale a Bebel, possuía características militares, a classe obreira permanecia sob a expropriação de uma dominação estrangeira, aquela do marxismo internacional, que combatia o Reich bismarckiano.

\section{b) $\mathbf{O}$ conflito acerca do orçamento militar}

O conflito constitucional de 1862-1866 foi o evento central da história prussiana da segunda metade do século 19. Ele re- 
velou, à luz do dia, o problema insolúvel posto pelo compromisso estabelecido entre a monarquia e o liberalismo. Ele se repete a cada projeto da Lei de finanças. Ele determina até a Constituição de Weimar, esta sendo apenas uma resposta tardia à questão política que punha este conflito. Ele termina aparentemente sob um compromisso: o governo realiza, em 1862, a reforma militar contra a vontade parlamentar; ele venceu duas guerras, contra a Dinamarca e após contra a Áustria; mas, após essas vitórias, ele solicitou e obteve da Dieta, em 05 de agosto de 1866, uma aprovação das despesas feitas sem autorização (a Lei da Indenização). As despesas do Estado têm necessidade de uma base legal, declara Guilherme I. A Doutrina fala de uma lacuna do direito: $o$ direito público termina aqui (Anschütz). Era reconhecido que o Estado não tinha uma constituição real, uma vez que esta, não resolvera a questão crucial do titular do poder orçamentário. Em caso de conflito, apenas o acordo entre o governo e o parlamento estava em condições de determinar o conteúdo da constituição.

O conflito constitucional termina, portanto, num compromisso dilatório. Ele foi dissimulado e superado graças aos sucessos diplomáticos e militares de Bismarck e após foi suspenso. Mas a questão decisiva, portanto, sob as forças armadas e seu financiamento permanecia em aberto. Segundo J. Barthélémy e após J. Rovan, as batalhas eleitorais e parlamentares repetidas em torno do voto dos créditos militares, estabelecidos nos orçamentos plurianuais (sete e após cinco anos), selaram a derrota do liberalismo alemão ${ }^{65}$. Ao invés dessa opinião geralmente admitida, Schmitt, em 1934 (mas, não em 1928), sustenta que o 5 de agosto de 1866 marca a submissão do Estado militar prussiano às concepções do constitucionalismo burguês. Um parlamento que tinha feito tudo por tornar impossíveis as vitórias de 1854 e de 1866,

${ }^{6} \quad{ }^{5}$ Cf. J. Barthélémy: "As teorias monarquistas na doutrina alemã contemporânea. Sobre as relações do Rei e das Câmaras nas monarquias particulares do Império", Revue du droit public, 1905, pp.717-758 ; J. Rovan: Le catholicisme politique en Allemagne. Histoire de la démocratie chrétienne II, Paris, Seuil, 1959, pp.69-73, $82,123$. 
contra o qual essas vitórias tinham sido alcançadas, foi solicitado para aprovar as despesas efetuadas sem sua autorização, se indigna o Jurista!

\section{c) A situação das forças armadas no Estado}

A constituição prussiana de 1850 - outorgada pelo rei, o que já não seria mais o caso das constituições de 1867 e 1871 - havia tentado conciliar a monarquia administrativa e militar com o sistema liberal, sob a base de um compromisso constitucional. Sob essa base, foi em seguida erigida a estrutura dualista do $2^{\circ}$ Reich. As forças armadas, impenetráveis ao direito público liberal, permanece no núcleo do Estado prussiano, portanto do Império Alemão. Enquanto que os funcionários juraram lealdade à constituição, não mais ao Rei, os militares, eles, continuaram a jurar lealdade ao rei. O corpo dos funcionários prussianos foi neutralizado e, pelo viés do princípio da legalidade da administração, submisso à lei, isto é, a representação parlamentar. Ele permanecerá fiel ao rei, mas apenas no quadro da legalidade do Estado de Direito, pois entre ele e o monarca se coloca a lei e a constituição. Em suma, não era mais a classe dirigente do Estado, como era ainda o caso da Prússia de Hegel. Ela adquiriu uma posição intermediária no conflito entre a monarquia militar e a burguesia liberal. Ao contrário, mantendo o juramento de fidelidade ao Rei e subtraindo seu comando militar à exigência do referendo ministerial, a força armada prussiana, escapou ao sistema do rechtsstaatlich.

A doutrina se resigna a esta situação inconstitucional da força armada. No dualismo geral do Estado se inscreve o dualismo particular da direção política e do comando militar. O Imperador da Alemanha e o Rei da Prússia eram, conforme a constituição, chefe militar irresponsável, em oposição, ao chefe político, responsável que era o Chanceler. Por causa desta ruptura entre o militar e o político, as forças armadas devem renunciar a toda função diretriz. Ela permanece, segundo a famosa divisa prussiana, a Escola da nação, graças ao serviço 
militar (ainda que ele não fosse de aplicação universal). Mas a ideia de direção e de educação aqui atingida referia-se apenas a uma ultima ratio: a guerra, no quadro do ofício militar. As forças armadas tornam-se assunto técnico, entrando em ação no quadro dos casos extremos e provisórios, quando ela deveria ter sido, dixit Schmitt, a educadora e reitora do povo alemão.

\section{d) Um Estado na defensiva}

A evolução intelectual do Século XIX, com a irresistível ascensão da democracia liberal, pôs o Estado militar prussiano na defensiva. Em 1934 e em 1937, Schmitt repete, de maneira um pouco menos polêmica, isto que ele dizia acerca de Weimar. Liberalismo, democracia ou socialismo se colocavam do lado do progresso, da liberdade e do futuro, enquanto que o Estado prussiano, frente a eles, parecia condenado ao fracasso.

Num contexto intelectual favorável, a argumentação liberal adquire uma preponderância política. Ela consegue impor sua própria definição de direito, de Estado de direito e de constituição, de liberdade e de igualdade. Em suma, o modo de pensar liberal invadiu e dominou o conjunto da vida cultural e da social. Aquilo que o Estado prussiano assumia por sua verdadeira constituição se transforma, segundo os liberais, em situação inconstitucional. O próprio governo monárquico aceitou esta substituição da concepção liberal de Estado à concepção prussiana. Guilherme I estava de acordo com seu Chanceler para pedir a aprovação parlamentar das despesas orçamentárias. Faltava à Prússia uma compreensão acerca dos conceitos de direito e de política (em termos gramscianos, um poder cultural). Roon escreveu em 1865: nossos adversários têm sem cessar tomado a iniciativa; pois as vantagens da iniciativa são, no combate intelectual como no combate militar, igualmente decisivas.

As conhecidas antíteses: direito/poder, Rechtsstaat/Machtstaat, agiram em desfavor do Estado prussiano e em favor da sociedade burguesa. Bennigsen, o líder dos liberais-nacionais, declarava que o Reich, pelo fato da posição das forças armadas, não 
tinha constituição no sentido do constitucionalismo. Ora, constituição não significa somente limitação dos poderes do Rei, mas sobretudo a negação da estrutura do Estado prussiano. Schmitt se interessa menos pela Monarquia que pela Força Armada. De outra parte sabe-se que o constitucionalismo culmina na instituição de uma jurisdição constitucional. Porém, se houvesse existido uma Corte Constitucional em 1866, aquela teria dado razão aos liberais e, portanto, impedido a unidade alemã.

\section{e) As disjunções constitucionais}

O compromisso inicial entre a monarquia militar e o constitucionalismo liberal se amplia sem cessar em detrimento do primeiro, pois leva a suprimir a direção política do povo por seu Rei e a relação do Rei com seu povo. Ele confere à representação nacional, isto é, ao Reichstag, o monopólio da interpretação da vontade geral interditando toda a relação imediata, tida por inconstitucional do governo com o povo e interpondo o sistema parlamentar dos partidos entre o governo e o povo, dividido pelos partidos. Após a saída de Bismarck, o Reich não teve mais a verdadeira direção política. O dualismo próprio ao Estado prussiano, estendido ao conjunto da constituição do Reich, tornava-se ainda mais complicado.

A expressão monarquia constitucional com o acento enganoso, posto sob a distinção da monarquia parlamentar, dissimulava as contradições do compromisso burguês-legitimista, contradições tornadas evidentes pela questão: soberania do povo ou do Rei? Princípio democrático ou monárquico? A expressão, Estado federal, dissimulava a contradição entre a confederação de Estados e o Estado nacional. A Estrutura do $2^{\circ}$ Reich se edifica sob esta dupla contradição. As decisões políticas fundamentais foram contornadas. O governo devia se ater a um jogo de equilíbrio, no qual o Chanceler de Ferro transformou-se em mestre. Ele contava com o Reichstag eleito pela nação face ao pluralismo dos Estados federados, sob a Prússia e o federalismo monárquico face ao pluralismo dos partidos, dois pluralismos que ameaçavam a unidade 
do Reich. O sentimento nacional, a força do Estado prussiano e a solidariedade dos monarcas do Bund constituíam a base política da unidade do Reich. Mas Bismarck não poderia assegurar sua direção política sem a maioria nacional-liberal no Reichstag. Antes de sua saída em 1890, ele terminou por reconhecer a necessidade de uma reforma da constituição da Alemanha. ${ }^{76}$

\section{O Reich wilhelmiano}

O império de Guilherme II apenas teve a aparência de uma constituição. Quem poderia governar num tal sistema de 24 estados? O Imperador da Alemanha e Rei da Prússia? O Chanceler imperial e Ministro Presidente prussiano? O Reichstag? O Bundsrat? Ou mesmo as forças armadas? Mas qual das forças, posto que, havia quatro contingentes e quatro ministérios da Guerra, de modo que reinava uma confusão extrema no domínio do orçamento militar? Se se tratava das forças prussianas, as quais de longe eram as mais importantes, quem a dirigiria? $\mathrm{O}$ Imperador e Rei? O Chanceler e Ministro-Presidente? O Chefe do Estado-Maior General[das forças armadas]? O Ministro da Guerra da Prússia? Em razão do caráter global de toda a questão política, cada uma destas autoridades poderia, em virtude de suas competências, reivindicar o poder de direção. Em realidade, uma tal estrutura constitucional não conhecia verdadeiramente o governo, mas apenas subgovernos e contragovernos.

A situação política da Alemanha exigia uma decisão, sem que fosse possível aguardar os resultados de uma evolução lenta. O Reich e seu governo: o Imperador, o Chanceler e os chefes dos Ofícios imperiais desenvolviam suas atribuições em detrimento da Prússia. A diferença de Guilherme I, Guilherme II parecia mais

\footnotetext{
${ }^{6}$ Schmitt fazia eco em 1929 em « Staatsstreichpläne Bismarcks und Verfassungslehre », republicado em Verfassungsrechtliche Aufsätze [VA] aus den Jahren 19241954. Materialen zu einer Verfassungslehre, Berlim, Duncker u. Humblot, 1958, pp.34-40.
} 
como um imperador alemão que como um rei prussiano. Nos anos críticos antes de 1914, era claro que a Prússia não governava mais e o Reich ainda não governava, entretanto era mantida a contradição entre federalismo, hegemonia prussiana e Estado Nacional. Em suma, o Reich entra na guerra mundial sem ter uma direção política! Os comentadores estrangeiros têm arguido que a separação do comando militar e da autoridade política não era um problema sério na Alemanha, pois o Imperador teria tido um poder ilimitado num Estado que não era parlamentar. Carl Schmitt quer refutar tal tipo de asserção, que repousa sob um exagero enganoso acerca da diferença entre a monarquia constitucional e monarquia parlamentar. Ele examina a configuração das relações político-constitucionais entre o Imperador e o Rei, o Chanceler e o Ministro-Presidente, o Bundsrat, o Reichstag e a Dieta prussiana, o Ministro da Guerra da Prússia.

\section{a) A Configuração das relações constitucionais centrais}

Enquanto chefe das forças armadas, o Imperador e Rei escapou da assinatura ministerial, portanto ao controle do parlamento. Mas, enquanto Chefe do Estado, ele dependia da assinatura do Chanceler e Ministro-Presidente, que tinha necessidade de uma maioridade parlamentar para votar as leis e o orçamento. Havia, pois uma cesura entre o comando militar, monárquico e a direção política, parlamentar: o Kaiser comandava as forças armadas sem governar politicamente, enquanto que o Kanzler governava politicamente sem comandar as forças armadas. Ademais, o Bundsrat, certamente dominado pela Prússia, tinha uma função importante em matéria legislativa e preponderante em matéria diplomática, no entanto ele decidia acerca da execução federal. Em suma, não havia governo monárquico: o Imperador e Rei tinha fora das forças armadas, apenas um poder indireto e, para dizer tudo, nenhuma possibilidade real de governar. Mesmo a proclamação do estado de sítio exigia o acordo do Chanceler. De maneira significativa é ao Bundsrat que foram concedidos os plenos poderes de 04 de agosto de 1914, cujo exercício era no 
entanto controlado pelo Reichstag.

O Chanceler e Ministro-Presidente era responsável diante do Imperador e Rei, enquanto que ele dependia para o voto das leis e do orçamento, do Bundsrat, assembleia dos Estados Monárquicos, do Reichstag, assembleia nacional eleita por sufrágio universal (masculino) direto, da Dieta prussiana, assembleia bicameral contendo uma Câmara alta aristocrática e uma Câmara Baixa composta por três classes. Além disso, ele apenas era o primus inter pares do colégio dos ministros do Reich ou da Prússia, nomeados pelo Kaiser und Koenig. Somente um fino estrategista como Bismarck, usando de seu direito de dissolução, pode criar um espaço para governar entre a responsabilidade ante o duplo monarca face às três assembleias e a dependência face a face das três Assembleias face ao duplo Monarca. Isso apenas foi possível com o apoio de uma maioria parlamentar, nacional-liberal, e graças às vitórias de 1864, 1866 e 1871.

As discussões parlamentares sobre os projetos de lei relativos às forças armadas mostraram que a lógica do constitucionalismo conduzia ao parlamentarismo. No meio da votação do orçamento militar, o Reichstag, que fazia às vezes de representação nacional e democrática face as câmaras provinciais e conservadoras constituídas pela Dieta prussiana, impede toda direção política independente dele, posto que ele tinha as forças armadas sob a dependência de sua aprovação orçamentária. A política sendo o Total, esta Totalidade é alcançada tanto do lado financeiro quando do lado militar. Entre a aplicação universal do serviço militar, estipulada pelo artigo 57 da Constituição de 1871, e as reivindicações orçamentárias do Reichstag, a balança pendia para o lado desses últimos (a Alemanha apenas apelava a metade da classe mobilizável antes de 1914 e apenas contava nesta data com 29.000 oficiais da reserva).

O ministro da Guerra prussiana encarna as contradições da estrutura dualista do Estado, pois ele estava no ponto de intersecção de todas as linhas de fratura da constituição bismarckiana. Seu domínio de ação foi rompido por todos os lados. Enquanto autoridade militar, ele era subordinado ao Imperador e Rei. 
Enquanto autoridade administrativa e financeira, ele dependia do Bundsrat, do Reichstag e da Dieta prussiana. Enfim, apenas a administração lhe retornaria, pois o comando pertencia ao Estado Maior. A abstrata separação do militar e do político, do militar e do civil, conduz à dissolução concreta da direção das forças armadas.

\section{b) A neutralização do Imperador e Rei}

Em 1939, Carl Schmitt retorna sobre a estrutura do II Reich e sobre a situação do Imperador e Rei. Ele se coloca, esta vez, do ponto de vista da neutralização do Chefe do Estado, que lhe impede de governar. A fórmula: o rei reina e não governa, terminou por se aplicar a Guilherme II. O processo de neutralização foi desenvolvido à sombra da antítese entre monarquia constitucional e monarquia parlamentar, sugerida por Stahl-Jolson e aceita pelos próprios conservadores prussianos. Para demonstrar o erro de tal antítese, que dá a ilusão de que a monarquia constitucional alemã reina e governa, o jurista se volta face aos iniciados e às testemunhas-chaves, aos arcanos do Reich wilhelmiano: von holstein e zu Eulenburg e, sobretudo, se refere às memórias do próprio Kaiser: Ereignisse und Gestalten aus den Jahre 1878 bis 1918 (Eventos e figuras dos anos de 1878 à 1918).

O II Reich não tinha um Imperador que governava realmente. Certamente o poder real na Prússia era forte, com o apoio das forças armadas e do funcionalismo público. O Rei não tinha ao seu lado um Ministro-Presidente responsável diante do Landtag, mas um colégio de ministros que dependiam de sua confiança. Apesar dessa posição, o conflito constitucional não pode ser evitado, em razão do poder legislativo e orçamentário devolvido à Dieta, mesmo sendo conservadora. Mas, a partilha federal do poder entre o Império e a Prússia permitiu a monarquia prussiana transferir o liberalismo ao Reich, a fim de proteger o Estado prussiano. Assim, por exemplo, o sufrágio igualitário torna-se uma realidade no Império, mas não no Reino. A clivagem entre liberalismo e conservadorismo se identifica assim perigosamente 
com a clivagem entre o Império e a Prússia. Igualmente, o conflito acerca dos efetivos das forças armadas e sobre o orçamento militar foi deslocado da Prússia ao Império. As forças armadas permanecem prussianas, mas seu orçamento cabe ao Reichstag, enquanto que os principais recursos fiscais, votados pelas Dietas, provinham dos Estados e da Prússia. Esse sistema complicado de repartição foi essencial para a história política do Reich wilhelminiano. Ele permite compreender a ideia de Guilherme II, em outubro de 1918, de renunciar à dignidade imperial resguardando a dignidade real. Na estrutura constitucional do II Reich, nem o Kaiser, nem o Reichsrat, nem o Reichstag governam. Apenas o Chanceler de Ferro consegue governar apoiando-se alternadamente sobre o Imperador e o Rei, sobre o Reichstag ou sobre a Dieta prussiana. Sua personalidade foi determinante, pois ele não era sustentado nem por um partido que ele teria sido o chefe, nem por uma classe social, nem mesmo pelas forças armadas e funcionalismo público, que eram da Prússia e se encontravam, portanto, subtraídas do Império. Esta forma de governo era no longo prazo insustentável. Ela já representa uma forma de neutralização do chefe de Estado.

As tentativas do Kaiser, por ser um monarca que governava de modo efetivo, fracassaram completamente. A vontade de lhe lembrar seus limites constitucionais e de lhe fixar na função de um chefe de Estado neutro, fez a unanimidade dos partidos do Reichstag, da esquerda à direita. Apesar dos rumores de golpe de Estado ou de golpe de Império, Guilherme II tinha de respeitar a constituição, que o ligava à assinatura de um Chanceler dependente de uma maioridade parlamentar para votar as leis e o orçamento. Em suas memórias, ele confirma a fraqueza de sua posição institucional. Enquanto Imperador, ele apenas poderia exercer influência política na medida concedida pelo Chanceler. Ele não tinha nenhum meio de forçá-lo seguir uma política que ele não queria assumir. Ao inverso, ele não podia impedi-lo de conduzir uma política que ele não aceitava. Ele tinha certamente a possibilidade de mudar de Chanceler; mas um tal procedimento difícil e arriscado, apenas, poderia ser uma ultima ratio, especial- 
mente porque o número de homens qualificados para ocupar um tal posto era muito restrito. In fine, o antigo Kaiser conclui que é fazer prova de uma completa ignorância da constituição do Império, querer tornar o Imperador o único responsável pelos eventos políticos. Segundo Schmitt, a versão dada por Guilherme II não é apenas uma construção a posteriori, destinada a desculpá-lo da desgraça da guerra mundial. Ela mostra o profundo erro da teoria da monarquia constitucional alemã, segundo a qual o rei continua a governar. Ao inverso, ela ilustra a neutralização do chefe do Estado, que corresponde à lógica do constitucionalismo. Ela conclui nisto que o Imperador, nos anos críticos de 1914 a 1918, apenas foi o supremo ouvinte e espectador do curso do mundo (von Moser). Hindenburg et Ludendorff, que usavam certamente de seu acesso privilegiado ao Kaiser, assumem o comando político e militar efetivo, sob o regime do Estado de sítio, que mantém as prerrogativas do Reichstag. Guilherme II, a despeito de sua posição de chefe militar supremo e apesar da pretendida diferença entre monarquia constitucional e monarquia parlamentar, não governa, porque, como ele diz dele mesmo, a constituição não o autorizava. A estrutura do II Reich apenas oferecia uma alternativa entre um poder neutro e um governo parlamentar ${ }^{87}$.

\section{c) As contradições constitucionais e o despreparo para a guer- ra}

A evolução face o parlamentarismo torna-se sempre mais evidente gradualmente e ao crescimento dos direitos políticos do Reichstag. As advertências do Estado-Maior sobre o despreparo militar da Alemanha permaneceram sem efeito e em razão das contradições internas do regime. Segundo o jurista, essas advertências são como documentos históricos desvelando a situação dramática do Reich wilhelmiano. No curso da guerra, o Estado-

\footnotetext{
87 « Neutralité et neutralisations... », pp.104-114.

110 - Universidade Católica de Pernambuco
} 
-Maior prova que ele podia e devia ser a instância dirigente: ao contrário de um Hans Delbrück, por exemplo, Carl Schmitt não critica a conduta da guerra por Hindenburg-Ludendorff. Mas os partidos interditaram essa orientação política, impelindo o Estado militar face a uma situação inconstitucional. Eles conseguiram o que falhou antes de 1866: impedir a preparação à guerra.

Põe-se o problema da aplicação universal do serviço militar, que teria permitido uma plena utilização dos recursos humanos disponíveis. De um lado, a estrutura de classe das forças armadas alemães limitava à criação de uma força armada nacional, isto é, de uma força armada popular cuja elite militar, aristocrática e prussiana temia que ela se tornasse uma força armada democrática e socialista. ${ }^{98}$ Por outro lado, o Reichstag refutava pelo antimilitarismo a extensão do serviço armado, ou aquele dos corpos de oficiais da reserva, e preferia a fixação dos efetivos a $1 \%$ da população. Schmitt insiste seguramente sobre este segundo aspecto. Se Bethmann-Hollweg, em 1913, não aprova a criação de três corpos da força armada de reserva suplementar, que Ludendorff, então chefe da Seção dos Efetivos, tinha reclamado ao ministro da Guerra, é porque ele temia que o Reichstag negasse votar o orçamento. Ora, quando da primeira batalha da Marne, a ausência desses três corpos se fez sentir pesadamente....Os conflitos de competência relativos ao recrutamento e ao financiamento da força armada reproduziam o antagonismo do Estado militar e do constitucionalismo, do Estado nacional e do federalismo.

Ernst Jünger falou da capacidade de mobilização total: a estrutura do II Reich impedia precisamente a capacidade de mobilização. Fissurada entre uma meia dúzia de instâncias, a direção

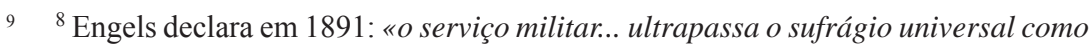
agente democrático. A força real da social-democracia alemã não reside no número de seus eleitores mas (naquele) de seus soldados... A força armada, uma vez... prussiana..., será socialista» (cf. S. Neumann : «Engels et Marx : concepts militaires des socialistes révolutionnaires », in E.M. Earle : Les maîtres de la stratégie, t.1 : De la Renaissance à la fin du XIXème siècle, Paris, Berger-Levrault, 1980, 1943, préf. R. Aron, pp.179-198, p.196).

Ano $13 \cdot$ n. $1 \cdot$ jan./jun. $2013-111$ 
política, condição da preparação à guerra, fez falta. As disjunções entre o político e o militar, o político e o econômico, o econômico e o militar, foram elevados ao grau de instituições conformes a constituição. Em 1866, o Estado prussiano tinha ao seu lado os sucessos diplomáticos e militares; o movimento liberal tinha ao seu lado o direito e a constituição. É sobre essa base que foi adiado o conflito. O que aconteceria na ausência do rápido sucesso militar? Qualquer burguesia se acomoda numa guerra curta e vitoriosa. Mas a existência do Estado não poderia depender apenas do sucesso das armas. Em que se tornaria o compromisso constitucional em sua condição fundamental: a vitória sobre o campo de batalha não seria mais completa?

\section{Da vitória do burguês sobre o soldado à restauração do Sol- dado}

A oposição liberal de 1866 termina por triunfar em 1918, exigindo e obtendo o estabelecimento de um regime parlamentar. A lógica do constitucionalismo termina por ter razão sobre a monarquia militar. Três soluções se apresentam para pôr fim à estrutura dualista do Estado: se um dos adversários se imporia sobre o outro, o soldado sobre o burguês ou o burguês sobre o soldado, criando assim uma decisão revolucionária; se a Alemanha renunciaria à potência política, tornando assim insignificantes suas contradições internas; se a Prússia sucumbiria heroicamente em plena consciência da posição perdida. Foi essa última possibilidade que adveio de 1914 à 1918. A República de Weimar herdou a derrota, antes de ser derrubada pelo movimento nacional socialista.

\section{a) Divisão, traição, revolução}

A tentativa do Imperador de tomar a direção dos negócios durante a guerra fracassou completamente. Todos os países beligerantes sabiam das tensões entre o comando militar e o governo civil. Essas tensões não são uma suposta oposição entre o militar e o político. Ao contrário, a indivisibilidade dos fins 
na guerra e dos fins da guerra, dos objetivos militares e dos fins políticos implica a instituição de uma direção integral, político-militar. Mas do fato da situação constitucional do II Reich, essas tensões atingiriam um grau de intensidade excepcional. Elas provocariam a Revolução de Novembro. A contradição da estrutura do Reich wilhelminiano se manifesta com uma acuidade redobrada quando a situação militar se degrada, quando as divergências sobre a conduta da guerra, notadamente a submarina, aparecem entre o Estado-Maior, o Chanceler, o Bundsrat e o Reichstag, rasgando assim o véu do compromisso constitucional.

Em 1864, 1866 e 1871, apesar das vitórias militares, o Estado prussiano se colocava na defensiva. Em 1914-1918, todo enfraquecimento diplomático ou militar no exterior deveria beneficiar o adversário interior, dando-lhe argumentos políticos para novas reivindicações jurídicas. Ao longo de uma guerra desesperada, no lugar de um reforçamento da unidade nacional, assiste-se a um aprofundamento da oposição entre a monarquia militar e o constitucionalismo liberal, até que a oposição torna-se mortal entre o governo e o povo, entre a força armada e a nação, entre o soldado e o trabalhador. A recusa dos créditos militares torna-se para os partidos traidores de seu país o ponto de ruptura constitucional. O Reichstag queria um reforço da imunidade parlamentar, a saber, o alargamento da brecha legal para a traição, e o parlamentarismo do regime, isto é, o estabelecimento do ideal político dos inimigos da Alemanha. O Autor de Der Führer schützt das Recht faz uma retrospectiva sobre os eventos de 1917-1918, que ele viveu, poderia dizer-se, em primeira linha, que ele era soldado atribuído à defesa. Ele menciona a sessão do Reichstag de 9 de outubro de 1917: ao comunicado do governo que se referia às relações entre os marinheiros amotinados e o USPD, fundado em 4 de abril, a Assembleia opunha as garantias constitucionais oferecidas aos partidos e argumentava, invocando o princípio nullum crimen, nulla poena sine lege, que faltavam as provas de 
alta traição ${ }^{1010}$.

Com a guerra e nas formas legais, o Estado de direito burguês triunfa sobre o Estado militar prussiano. Após a reforma eleitoral na Prússia de 12 de julho de 1917 e o voto da resolução de paz de 19 de julho que provocaram a queda Bethmann-Hollweg e sua substituição por Michaelis, o Reichstag exigia que o Chanceler pudesse assinar todas as decisões relativas à força armada tomadas pelo Imperador. Os últimos chanceleres do II Reich, Hertling e Max de Bade, eram os ministros parlamentares responsáveis diante do Reichstag. As leis constitucionais de 28 de outubro de 1918 foram a conclusão lógica do constitucionalismo do século XIX. Como Anschütz disse: a instituição militar foi subordinada ao parlamento, suprimindo assim o militarismo prussiano em contradição com os princípios rechtsstaatlichen. Com Anschütz, é a doutrina liberal do direito público, puramente jurídica e pretensamente apolítica, que prevalece, fulmina Schmitt. Ao mesmo tempo em que o liberalismo triunfava do militarismo, a força armada se deslocava e o Reich capitulava.

\section{b) Da submissão intelectual à submissão política}

Acredita-se camuflar as decisões em política interior pelos sucessos na política exterior. Mas o inimigo interior é mais importante que o inimigo exterior e as vitórias militares não atenuam os defeitos intelectuais. O estabelecimento além Reno de uma República democrática e liberal apenas é o coroamento de um longo processo de infiltrações estrangeiras as quais se deve $a$ derrocada do II Reich. Em três momentos decisivos da história do século XIX, a submissão à concepção jurídica do adversário teve uma influência funesta sobre o destino da Alemanha.

O primeiro momento foi em 1866, quando Bismarck solicita à Dieta a aprovação retroativa das dispensas orçamentárias feitas sem autorização. Parece sem importância consentir

\footnotetext{
1010 « Der Führer schützt das Recht », pp.199-200.

114 - Universidade Católica de Pernambuco
} 
às concepções jurídicas do rival em política interior. De fato, foi estabelecida a lei fundamental do desenvolvimento histórico que findou no desastre de 1918. O segundo momento ocorreu em 1914. A guerra começou por uma demissão intelectual, quando Bethmann-Hollweg justificou a entrada na guerra do Reich como a luta contra a Rússia czarista. ${ }^{1{ }^{11}} \mathrm{O}$ jurista faz alusão ao voto dos créditos de guerra quando da sessão do Reichstag em 4 de agosto: para se assegurar que as vozes do SPD detinham a maioria relativa desde 1912, o chanceler declara que se trata de uma guerra contra o czarismo, o que correspondia à ideologia da social democracia. O povo alemão, que combatia por sua existência nacional, foi engajado no conflito sob a égide de ideais da Internacional socialista, que eram, ao mesmo tempo, aqueles dos inimigos exteriores da Alemanha e aqueles dos inimigos internos do Estado prussiano. Mas a submissão aos conceitos políticos de inimigo toma uma extensão maior ainda. No mesmo dia, o Chanceler declara que a invasão da Bélgica pela força armada alemã era um erro que precisava reparar. Tal propósito ${ }^{12} 2$ assinala um novo reagrupamento às concepções político-jurídicas dos adversários de dentro e de fora, ilustradas pela máxima pacta sunt servanda. $\mathrm{O}$ terceiro momento realiza esta evolução : nas leis de 28 de outubro de 1918, a ideia parlamentar significa a derrota da força armada. A estas três datas: 5 de agosto de 1866, 4 de agosto de 1914 e 28 de outubro de 1918, Schmitt as coloca sobre uma mesma linha de desenvolvimento histórico, aquela que vai da abdicação intelectual à submissão política: de início, a submissão às concepções jurídicas do liberalismo: depois, a submissão à argumentação do inimigo exterior a fim de conciliar o inimigo interno que minou a partilha da ideologia; enfim, a submissão aos ideais constitucionais dos Aliados e a renúncia às tradições prussianas.

\footnotetext{
${ }^{11}{ }^{11}$ Que a esquerda sempre considerava, ao estímulo de Marx e Engels, como a citadela da reação.

${ }^{12}{ }^{12}$ Que faz alusão à violação da neutralidade belga, convencionalmente garantida à época.
} 
Em 1919, foi adotado com a constituição de Weimar o tipo de Estado correspondente à democracia ocidental, última conclusão de uma submissão iniciada subrepticiamente meio século antes. O ideal inglês de burguês venceu (provisoriamente) o ideal alemão do soldado, declara o jurista em 1937. A preparação para a guerra foi submissa ao compromisso constitucional: cinquenta anos de tratados internos entre o Estado prussiano e seus adversários precederam ao Tratado de Versalhes. ${ }^{13_{13}}$ É, portanto, essencial o combate intelectual contra a recepção de um pensamento estrangeiro do Estado e do direito. Nós terminamos por reconhecer que as constituições liberais tornaram-se modos sob os quais os estrangeiros dissimularam sua dominação. Bismarck cometeu o erro de reduzir o problema da aprovação parlamentar das despesas orçamentárias a uma querela de palavras. No compromisso constitucional, em efeito, cada um podia acreditar que tinha acordado qualquer coisa com o outro: o rei acordava a demanda de aprovação (interpretação monárquica), o Reichstag acordava a aprovação (Interpretação parlamentar). Mas, uma controvérsia conceitual linguística e jurídica pode tornar-se um negócio político pleno de consequências. O Chanceler de Ferro teria dito sem dúvida, pois ele tinha claramente reconhecido o sentido polêmico da expressão Estado de Direito, no momento do conflito com o Zentrum e o SPD.

\section{c) Da Constituição póstuma à Constituição Alemã}

Os chefes de partido e os políticos profissionais de oposição parlamentar foram forçados, em 1918, a provar a precisão de seu combate contra o Estado militar prussiano através das realizações políticas, no lugar dos habituais discursos contra o militarismo inconstitucional. A constituição de Weimar foi uma

\footnotetext{
1313 « Totaler Feind, totaler Krieg, totaler Staat», in Positionen und Begriffe im Kampf mit Weimar, Genf, Versailles, 1923-1939, Hambourg, Hanseatische Verlagsanstalt, 1940, pp.238-239.
} 
resposta às questões postas pelo conflito constitucional. Ela não foi uma constituição intermediária (Walz), mas a parte burguesa da constituição dualista de Estado que subsistiu e triunfou após o desaparecimento da parte prussiana.

Se o artigo 25 dispõe que o Presidente do Reich apenas pode dissolver a Assembleia uma única vez pelo mesmo motivo, é em resposta às dissoluções repetidas por Bismarck. ${ }^{1{ }_{14} 4} \mathrm{Se}$ o artigo 50 dispõe que todos os seus decretos, mesmo os concernentes às forças armadas, devem ser assinados, em resposta às velhas exigências do Reichstag. Segue o mesmo caminho a supressão da jurisdição militar segundo o artigo 106 ou da regulamentação do serviço militar pela lei segundo o artigo 133-2. Se o artigo 85 dispõe que todas as despesas do Reich, devem ser previstas e inscritas num orçamento anual estabelecido pela lei, é em respostas às antigas querelas e práticas sobre o orçamento militar. Se o artigo 176 dispõe que os membros da Reichwehr devem prestar juramento à constituição, é em resposta ao antigo juramento de fidelidade que era dirigido ao soberano.

Mas esta vitória foi uma vitória póstuma. Schmitt afirma desde $1928^{1515}$; ela foi a resposta a uma questão que não se colocava mais, posto que o Estado militar prussiano, o adversário, não existia mais. Nos anos de 1928-1932 ${ }^{1616}$, o jurista via no bolchevismo o novo inimigo designado da constituição weimariana, que havia dado um novo vigor ao liberalismo. Em 1934, esta não é mais a questão: esta constituição volta-se para o passado, é simplesmente a vitória que um fantasma alcança sobre a sombra de seu adversário. Ela foi um compromisso, não mais entre a monarquia militar e o constitucionalismo, mas entre três visões de mundo contraditórias: catolicismo, liberalismo e marxismo. A

\footnotetext{
${ }^{14}{ }^{14}$ Cf. « Reichstagsauflösungen » (1924), in VA, pp.13-28.

1515 Théorie de la constitution, p.483 ; «O Estado de direito burguês», p.31; cf. aussi Hugo Preuss..., p.22.

${ }^{16}{ }^{16}$ Théorie de la Constitution, pp.161-162, 166 ; Hugo Preuss..., p. 17 ; « Inhalt und Bedeutung des zweiten Hauptteils des Reichsverfassung », pp.582-583.
} 
evolução ulterior desse compromisso conduziu ao sistema pluralista. A lógica rechtsstaatlich aproveita certas forças políticas organizadas, principalmente o Zentrum e o SPD, os inimigos de Bismarck.

De dualista, a estrutura do Estado torna-se então pluralista: ao dualismo do Soldado e do Burguês sucede o pluralismo dos partidos. Mas, a esse pluralismo escaparam os dois pilares do antigo estado prussiano: a função pública e a força armada, sob a direção do Reichspräsident. Esse, ao nomear Hitler como Chanceler, permitiu ao movimento nacional-socialista alcançar o poder. Esse movimento, saído da resistência contra as forças responsáveis pela derrocada de 1918, substituiu a estrutura dualista, depois pluralista de Estado, e a teoria do direito e do Estado que foi coordenada, por uma nova forma de unidade política repousando sobre o Estado, o Movimento e o Povo (Staat, Bewegung, Volk). Liberando a Alemanha do constitucionalismo, isto é de um princípio estranho e ultrapassado, ele nos reconduziu à nós mesmo enquanto Alemanha, concluiu Schmitt. ${ }^{17_{17}}$

\section{d) A força armada no Reich nacional-socialista}

Mas, ele se engana, adiante, sobre a situação da força armada no Estado nacional-socialista. Aquela que, no dia seguinte ao dia 30 de junho de 1934 (expurga as SA), crê ter alcançado uma grande vitória e, certamente, ela ocupa um lugar central neste Estado militar que é o III Reich. Mas em 1938, Hitler suprimirá o privilégio do Estado-Maior de ser juiz das implicações militares da política estrangeira. Paralelamente, com a supressão do ministério da guerra e a criação do OberKommando der Wehrmacht, ele exercerá diretamente sua autoridade sobre as três forças armadas, terra (Heer), mar (Marine), ar (Luft). Em 1916-18, o Estado-Maior tinha assumido a direção da guerra: a partir de 1938, ele não será mais que um órgão de execução. A economia da guerra,

\footnotetext{
$17 \quad{ }^{17}$ Staatsgefüge und Zusammenbruch des Zweiten Reiches..., p.43.

118 - Universidade Católica de Pernambuco
} 
confiada à Goering em 1936, depois a Speer em 1942, não ficará a cargo da autoridade militar, como tinha sido o caso em 191718. A concorrência da SS, a força armada do Partido, se tornará crescente, com o desenvolvimento da Waffen SS e a absorção pela Sicherheitsdienst da Abwehr (o serviço de informações da Wehrmacht).

Todavia, em 1934, uma coisa é certa: a reforma política tornará possível, não apenas o re-armamento, mas a reforma militar. A força armada alemã poderá retornar a ser uma força armada nacional, sem risco de submersão ou de deslocação da instituição militar. É assim que, em março de 1935, o serviço militar obrigatório, igual e universal, é estabelecido com a primeira lei sobre a reconstrução da Wehrmacht (a segunda em maio fará de Hitler o comandante em chefe, investido do poder de decretar a mobilização e de declarar a guerra). Enfim, a preocupação do governo e do Estado-Maior será de evitar os erros do passado e de eliminar tudo o que seria de natureza a provocar o retorno de uma derrota. Em razão da unidade do comando político e militar, todo o risco de conflito constitucional se encontraria afastado. Em razão da supressão dos contingentes de países, toda compartimentação territorial será abolida. Em razão da Direção do Plano sobre a Economia e a Organização do Trabalho, o conjunto dos recursos humanos, industriais e agrícolas se encontrarão mobilizados para a defesa nacional. Enfim, pela lei do trabalho de 19 de abril de 1936, sobre a proteção do espírito patriótico, o Estado será dotado de um instrumento eficaz contra a subversão e a sedição. ${ }^{1818}$

${ }^{18}{ }^{18}$ Cf. H. Speier : « Ludendorff: a concepção alemã de guerra total», in E.M. Earle, op. cit., t.2 : De la fin du XIXème siècle à Hitler, 1981 (1943), pp.31-48 ; Ph. Masson : Histoire de l'armée allemande, 1939-1945, Paris, Perrin, 1994, pp.42-50, 492493. 


\section{Referências}

SCHMITT, Carl. L'Etat de droit bourgeois, in $\mathrm{Du}$ politique. "Légalité et légitimité » et autres essais, Puiseaux, Pardès, 1990, préf. A. de Benoist, pp.31-38, trad. de « Der bürgerliche Rechtsstaat » (1928)

. Théorie de la Constitution, Paris, PUF, 1993, préf. O. Beaud, trad. de Verfassungslehre (1928).

. Hugo Preuss. Sein Staatsbegriff und seine Stellung in der deutschen Staatslehre, Tübingen, J.C.B. Mohr, 1930.

- Nationalsozialismus und Rechtsstaat, in Juristische Wochenschrift, 12-13, 24 mars 1934, pp.713-718.

. Der Führer schützt das Recht. Zur Reichstagrede Adolf Hitler vom 13. Juli 1934 , in Positionen und Begriffe [PuB] im Kampf mit Weimar, Genf, Versailles, 1923-1939, Hambourg, Hanseatische Verlagsanstalt, 1940, pp.199-201, trad. française in Cités, n¹4, 2003, « Le Führer protège le droit. A propos du discours d'Adolf Hitler au Reichstag du 13 juillet 1934 », pp.165171.

. Staatsgefüge und Zusammenbruch des Zweiten Reiches.

Der Sieg des Bürgers über den Soldaten, Hambourg, Hanseatische Verlagsanstalt, 1934.

- Die Verfassung der Freiheit, in Deutsche JuristenZeitung, XL, 19, 1er octobre 1935, pp.1134-1135, trad. française in Y.-Ch. Zarka : Un détail nazi dans la pensée de Carl Schmitt, Paris, PUF, 2005, La Constitution de la liberté, pp.53-57.

. Totaler Feind, totaler Krieg, totaler Staat (1937), in

PuB, pp.235-240

- Neutralité et neutralisations. A propos de: Christoph Steding, Das Reich und die Krankheit der europäischen Kultur », in Du politique..., pp.101-126, trad. de Neutralität und Neutralisierungen. Zu Christoph Steding 'Das Reich und die Krankheit der europäischen Kultur'(1939).

. Terre et Mer. Un point de vue sur l'histoire mondiale, Paris, Labyrinthe, 1985, trad. de Land und Meer. Eine weltgeschichtliche Betrachtung (1942). 